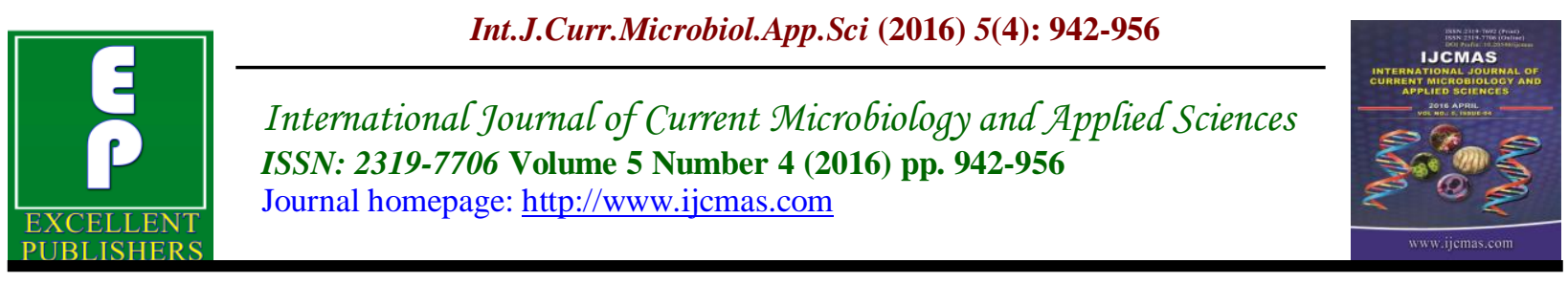

Original Research Article

http://dx.doi.org/10.20546/ijcmas.2016.504.107

\title{
Insecticide and Salt Tolerance of Plant Growth Promoting Root Nodule Bacteria
}

\author{
V. Nithyakalyani ${ }^{1,2 *}$, M. Kannan ${ }^{3}$ and Ramya Anandan ${ }^{1,2}$ \\ ${ }^{1}$ Research \& Development Centre, Bharathiar University, Coimbatore- 641 046, India \\ ${ }^{2}$ Department of Microbiology, Dr. MGR Janaki College of Arts and Science for Women, \\ Chennai- 600028, Tamil Nadu, India \\ ${ }^{3}$ Department of Microbiology, V. H. N. S. N. College, Virudhunagar 626001, Tamil Nadu, India \\ *Corresponding author
}

Keywords

Rhizobium, Carbaryl, Salt, Growth Factors, IAA, EPS, HCN.

\begin{tabular}{l}
\hline Article Info \\
\hline Accepted: \\
25 March 2016 \\
Available Online: \\
10 April 2016
\end{tabular}

A B S T R A C T

The objective of this study was to characterize the rhizobial isolates obtained from root nodules of Arachis hypogaea plants and to investigate their tolerance efficiency towards salt and Carbaryl insecticide based on growth response analysis. The isolates were then tested for IAA, EPS and $\mathrm{HCN}$ production. Eight isolates viz., S1, S2, S3...S8 were found to be tolerant to high concentrations of salt and insecticide. Growth response analysis studies indicated that the tolerance ability of the organisms varied. Of all the strains, S5 showed high salt and pesticide tolerance and produced substantial amounts of growth factors. Therefore, S5 bacteria may be beneficial to improve growth and development of leguminous plants. Further studies are needed to characterize the strains on molecular basis and to substantiate the results through pot and field cultivational studies under stress conditions.

\section{Introduction}

The United Nations Food and Agriculture Organization (FAO) estimates that the total demands for agricultural products will be 60 percent higher in 2030 than present time. And more than $85 \%$ of this additional demand will come from developing countries. For over half a century, the world has relied on increasing crop yields to supply an ever increasing demand for food. In order to increase world food production in a sustainable manner, farmers have to use balanced fertilizer timely. One of the most important factors in the generation of high yields is nitrogen fertilizer. That is why farmers are applying high amounts of the fertilizers which is very costly and make the environment hazardous especially when use discriminately. In addition, more than $50 \%$ of the applied $\mathrm{N}$-fertilizers are somehow lost through different processes which not only represent a cash loss to the farmers and consequently polluted the environmental. 
Crop scientists all over the world are facing this alarming situation and they are trying to overcome this condition by exploring alternative sources which is cost effective and save the environment.

Biofertilizer, an alternative source of $\mathrm{N}$ fertilizer, especially rhizobia in legume symbiosis is an established technology. Use of the biofertilizers can also prevent the depletion of the soil organic matter (Jeyabal and Kuppuswamy, 2001). Inoculation with bacterial biofertilizers may reduce the application of fertilizer- $\mathrm{N}$ by increasing $\mathrm{N}$ uptake by plants (Choudhury and Kennedy, 2004; Kennedy et al., 2004; Mia et al., 2005 and 2007). But most of this technique mainly limited between legume and Rhizobium in symbiotic process, which can fix atmospheric $\mathrm{N}_{2}$. However, biological $\mathrm{N}_{2}$ fixation (BNF) technology can play a vital role in substituting for commercially available $\mathrm{N}$-fertilizer, thereby reducing the environmental problem to some extent. Nitrogen fixation and plant growth enhancement by rhizosphere bacteria might be important factors for achieving a sustainable agriculture in the future.

The legume-rhizobia interaction is the result of specific recognition of the host legume by Rhizobium. Various signal molecules that are produced by both Rhizobia and the legume confer the specificity (Phillips, 1991). Exo polysaccharide (EPA) produced by Rhizobium is one such signal for host specificity during the early stage of root hair infection (Olivers et al., 1984; Raghavendra joshi and Padder, 2002). It also protects the cell from desiccation and predation and helps in nitrogen fixation by preventing high oxygen tension (Jarman et al., 1978). In addition, Rhizobium strains secrete growth hormones like Indole acetic acid (IAA), which shows positive influence on plant growth and also plays an important role in the formation and development of root nodules (Nutman, 1977). Hence, the production of EPA and IAA are considered as important traits of plant growthpromoting rhizobacteria.

Several environmental conditions are the limiting factors to the growth and activity of nitrogen-fixing plants. Typical environmental stresses faced by the legume nodules and the symbiotic partners may include water stress, salinity, soil $\mathrm{pH}$, temperature, heavy metals, pesticides and so on (Cigdem Kucuk 2008).Within the soil, Rhizobium bacteria encounter various stresses that affect their growth, their initial steps of symbiosis and the capability of nitrogen fixation (Ramadoss and Sivaprakasam, 1991). Symbiotic nitrogen fixation is commonly limited by soil infertility conditions including salinity. Detrimental effects of salt on the survival and growth of Rhizobium in the environment have been reported (Yadav and Vyas 1963). In addition, the presence of high sodium chloride concentration has also been reported to cause a reduction in the number of Rhizobium in legume inoculants (Steinborn and Roughley 1974). Thus tolerance to salt stress is an important part of saprophytic competence and competitiveness in Rhizobium.

Pesticides are the important agrochemicals used for prevention of crops from pests. Their use has been largely increased in last few decades. The application of pesticides starts from the pre sowing stage. Different treatments include soil application, seed treatment, foliar spray, etc. Repeated applications of pesticides contaminate the soil. Soil is the most important site of biological interactions. The indiscriminate use of pesticides disturbs the soil environment by affecting flora and fauna including micro flora of soil, and also the 
physicochemical properties of soil like $\mathrm{pH}$, salinity, alkalinity leading to infertility of soil. The important micro flora, beneficial for the growth of plants includes nitrogen fixing bacteria and phosphate solubilizing bacteria, present in the rhizosphere of the plant. The excess application of these pesticides may adversely affect the function of these rhizospheric microorganisms. An insecticide is a pesticide used against insects. They include ovicides and larvicides used against the eggs and larvae of insects respectively. The use of insecticides is believed to be one of the major factors behind the increase in agricultural productivity in the 20 th century.

Carbaryl is a wide-spectrum carbamate insecticide which controls over 100 species of insects on citrus, fruit, cotton, forests, lawns, nuts, ornamentals, shade trees, and other crops, as well as on poultry, livestock and pets. It is also used as a molluscicide and an acaricide. Carbaryl works whether it is ingested into the stomach of the pest or absorbed through direct contact. The chemical name for Carbaryl is 1- naphthol $\mathrm{N}$-methylcarbamate.It is found in all types of formulations including baits, dusts, wettable powder, granules, oil, molasses, aqueous dispersions and suspensions. Carbaryl is a general use pesticide. Carbaryl, commonly sold under the brand name Sevin, a trademark of the Bayer Company. Union Carbide discovered Carbaryl and introduced it commercially in 1958. Bayer purchased Aventis Crop Science in 2002, a company that included Union Carbide pesticide operations. It remains the third most-used insecticide in the United States for home gardens, commercial agriculture, and forestry and rangeland protection. Approximately 11 million kilograms were applied to U.S. farm crops in 1976. Trade or other names: Carbamine, Denapon, Dicarbam, Hexavin, Karbaspray, Ravyon,
Septene, Sevin, Tercyl, Tricarnam, and Union Carbide. In this study, Rhizobium isolated from Arachis hypogaea from different sites were analyzed for its growth response against different concentrations of sodium chloride and insecticide, Carbaryl. This response was then analyzed on the basis of the change in growth rate and total nitrogen fixation by Micro-Kjeldahl's method. The strains were also screened for the production of IAA, EPS and HCN. This resistance study to the observed stress parameters and growth factors production studies could lead to the selection of efficient isolates for agricultural practices.

\section{Materials and Methods}

\section{Isolation of Rhizobium from Leguminous Roots}

Roots of leguminous plants were washed with running tap water to remove adhering soil particles. Healthy, unbroken and firm root nodules were selected and washed with running tap water. The nodules were immersed in $0.1 \% \mathrm{HgCl}_{2}$ for five minutes to surface sterilize.The nodules were washed repeatedly in sterile water for 3-4 times to get rid of the sterilizing agent.The nodules were placed in $70 \%$ Ethyl Alcohol for 3 minutes. The nodules were washed repeatedly in sterile water. The nodules were crushed in $1 \mathrm{ml}$ of water with a sterile glass rod. An aliquot of the sample is then diluted and streaked on the surface of YEMA plates containing Congo Red. The plates were incubated at $25-28^{\circ}$ Celsius for 3-10 days until colonies appear. An isolate from a single Rhizobial colony is then confirmed as Rhizobium by microbiological assays.

Eight Rhizobium isolates were isolated from Groundnut fields in Vellore district of Tamil Nadu. Rhizobium leguminosarum MTCC No.99 was used as a standard and was 
procured from IMTECH, Chandigarh. The cultures / isolates were maintained on Yeast Extract Mannitol Agar with Congo red with sub culturing done once in every fifteen days to keep the cells viable.

\section{Microbiological Assays}

\section{Gram Staining and Motility}

Gram staining reaction and motility testing was performed.

\section{Yeast Extract Mannitol Agar}

Yeast extract Mannitol agar with Congo red was prepared and a loopful of the culture was streaked onto the agar plates. The plates were incubated at room temperature overnight.

\section{Glucose Peptone Agar (GPA)}

GPA medium was prepared and a loopful of the culture was streaked onto appropriate plates. The plates were incubated and observed for growth.

\section{Gelatin Hydrolysis}

Nutrient gelatin medium was prepared. Actively grown cultures were inoculated onto the medium and incubated for 48 hours.

\section{Starch Hydrolysis}

Starch agar medium was prepared and inoculated with Rhizobium, incubated and analyzed. Iodine test was used to determine capability of microorganisms to degrade starch. Drops of iodine solution $(0.1 \mathrm{~N})$ were spread on 24 hours old cultures grown on petriplates.

\section{Fluorescence Assay}

King's medium was prepared and incubated aseptically with Rhizobium cultures. It was incubated at $29.4^{\circ}$ Celsius for 48 hours and the observations were made under UV-light source.

\section{Mannitol - Motility Test}

Mannitol motility test medium was prepared. Appropriate cultures were inoculated and left for overnight incubation.

\section{Bromothymol Blue Test}

Bromothymol blue was added to the growth medium. The culture was streaked onto the agar plates and checked for growth. Plates were incubated at room temperature for 24 hours.

\section{Test for Salt Tolerance}

The ability of the isolates to grow in different concentrations of salt was tested by streaking isolates on YEM media containing sodium chloride in different concentrations from $0.000 \mathrm{M}$ to $0.800 \mathrm{M}$. Yeast Extract Mannitol agar was prepared by adding sodium chloride at different concentrations. The isolates were streaked onto the prepared YEMA plates. The plates were incubated at room temperature overnight (24 hours).Results were tabulated according to the growth observed on the agar plate.

\section{Impact Analysis of Insecticide on the Rhizobial Cultures}

INSECTICIDE Carbaryl 50\% (WP) was procured from Tamil Nadu Horticulture Department, Anna Salai, Chennai. For the analysis of impact of the various concentrations of fungicide on the rhizobial cultures, Yeast Extract Mannitol Broth cultures of various isolates were used.50ml of Yeast Extract Mannitol Broth was prepared in $100 \mathrm{ml}$ conical flask, sterilized 
by autoclaving and cooled to room temperature. For the analysis, each of the isolate was inoculated into the various flask containing different concentrations of the fungicide. [100 $\mu \mathrm{g} / \mathrm{ml}, 200 \mu \mathrm{g} / \mathrm{ml}, 400 \mu \mathrm{g} / \mathrm{ml}$, $600 \mu \mathrm{g} / \mathrm{ml}, \quad 800 \mu \mathrm{g} / \mathrm{ml}, \quad 1000 \mu \mathrm{g} / \mathrm{ml}$, $\quad 1200 \mu \mathrm{g} / \mathrm{ml}, \quad 1400 \mu \mathrm{g} / \mathrm{ml}, \quad 1600 \mu \mathrm{g} / \mathrm{ml}$, $1800 \mu \mathrm{g} / \mathrm{ml}$ and $2000 \mu \mathrm{g} / \mathrm{ml}$. The flasks were kept for incubation at room temperature on a rotary shaker overnight. After incubation, Yeast Extract Mannitol Agar with Congo red was prepared and poured onto sterile petriplates. A loopful of the broth from the different flasks was streaked onto the agar plates correspondingly labeled to check for growth. The plates were incubated at room temperature overnight ( 24 hours). Results were tabulated according to the growth observed on the agar plate.

\section{Growth Response Analysis to the Insecticide}

To study the growth response to the insecticide at $2000 \mu \mathrm{g} / \mathrm{ml}$, the isolates were cultured in YEMB with $2000 \mu \mathrm{g} / \mathrm{ml}$ test insecticide and a control was maintained by culturing the isolates in YEMB without test insecticide. Two $50 \mathrm{ml}$ of YEM Broth per isolate to be analyzed was prepared and autoclaved. To one of the set of the flask $2000 \mu \mathrm{g} / \mathrm{ml}$ test insecticide was added.

Corresponding isolates were inoculated into each of the 2 conical flasks with YEM Broth and left for overnight incubation at room temperature on a rotary shaker. After 24 hours, An aliquot of the overnight broth culture was added to fresh YEM Broth and the growth was measured turbidimetrically for every half an hour. The generation time was calculated using the formula:

$$
\mathrm{n}=\frac{\log _{10} \mathrm{~N}-\log _{10} \mathrm{~N}_{0}}{\log _{10} 2}
$$

Generation time $=t / n$

\section{Estimation of Total Nitrogen Fixed by Micro-Kjeldahl Method}

The total nitrogen fixed by the selected rhizobial cultures were estimated by MicroKjeldahl's method. The strain of rhizobia that showed no resistance to insecticide was inoculated into YEMB. The MTCC and the resistant strains of rhizobia were inoculated into YEMB with $2000 \mu \mathrm{g} / \mathrm{ml}$ of insecticide. Similar strains grown without insecticide were used as control. All the above cultures were incubated for 48 hours in a rotary shaker at room temperature.

\section{Sample Preparation}

A known weight of the sample was taken and mixed with $7.5 \mathrm{~g}$ of sodium sulphate and $0.5 \mathrm{~g}$ of copper sulphate.Digestion procedure was carried out with $15 \mathrm{ml}$ of concentrated sulphuric acid.Digested samples were distilled with $32 \%$ sodium hydroxide $(90 \mathrm{ml})$ until all ammonia passed over into boric acid $(50 \mathrm{ml})$. The mixture was then titrated with the standard $0.1 \mathrm{~N}$ Hydrochloric acid along with the blank.

Calculation:

$\mathrm{N}_{2}=\frac{\text { (sample-blank) } \times 1.4007 \times \mathrm{N} \text { of Hcl }}{\text { weight of the sample }}$

Screening of Isolates for Indole Acetic Acid Production

Isolated strains were inoculated in YEM medium supplemented with $0.1 \%$ tryptophan into different flasks. Controls were maintained (YEM without tryptophan). The cultures were incubated in a shaker for 72 hours. Cultures were centrifuged at $3000 \mathrm{rpm}$ for 30 minutes. Supernatant was removed and $2 \mathrm{ml}$ of supernatant was mixed with $4 \mathrm{ml}$ of Solawaski's reagent $(98 \mathrm{ml}$ of $35 \%$ perchloric acid was mixed with $2 \mathrm{ml}$ of ferric chloride). Mixture was incubated at room temperature 
for 25 minutes and observed for pink colour which indicates Indole Acetic Acid production. The amount of IAA production was determined by spectrophotometer at 540 $\mathrm{nm}$. The amount of IAA produced by isolated strains was determined using standard graph.

\section{Preparation of Standard Graph of IAA}

Different standard IAA concentrations were prepared as aqueous solution of IAA ranging from $10 \mu \mathrm{g}$ to $100 \mu \mathrm{g}$. To each of $1 \mathrm{ml}$ of the standard, $2 \mathrm{ml}$ of Solawaski's reagent was added. Readings were taken after 25 minutes incubation at $530 \mathrm{~nm}$ by UVspectrophotometer. Standard graph was prepared by plotting concentration of IAA in micrograms $/ \mathrm{ml}$ Vs optical density at $530 \mathrm{~nm}$.

\section{Screening of Isolates for Extrapolysaccharide (EPS)}

YEM broth was prepared in $100 \mathrm{ml}$ conical flasks. The broths were supplemented with $1 \%$ carbon source (glucose). Broth was sterilized and cooled to room temperature. Isolated strains were inoculated into sterilized broth. Inoculated flasks were incubated at room temperature on a shaker for 72 hours. After incubation, the culture broth was centrifuged at $3500 \mathrm{rpm}$ for 30 minutes. $1 \mathrm{ml}$ of supernatant was mixed with two volumes of chilled acetone.

The crude polysaccharide developed was collected by centrifugation at $3500 \mathrm{rpm}$ for 30 minutes. The EPS was washed with distilled water and acetone alternately. EPS was transferred into a filter paper and weighed after overnight drying at room temperature. Results were tabulated according to the weight measured after overnight incubation and expressed as $\mu \mathrm{g} / \mathrm{ml}$.

\section{Screening of Isolates for Hydrogen Cyanide (HCN) Production}

Nutrient agar was prepared and glycine (4.2\%) was added. After sterilization, sucrose $(1 \%)$ was added to sterilized nutrient agar medium. Agar was poured into sterilized petriplates. After solidification isolated strains were streaked onto nutrient plates. Picric acid dipped filter papers were kept under the lid of the streaked petriplates. Plates were incubated for 2 to 4 days at room temperature. Results were tabulated according to the red-orange color formation on the filter paper.

\section{Results and Discussion}

Eight isolates obtained from root nodules of Groundnut plant showed designated as S1, S2...S8 showed Gram negative reaction and were highly motile. The isolates, on YEMA showed 2mm, circular, colorless, raised, smooth, translucent, highly mucoid colonies with musky odor was observed. Rhizobial cells were able to grow on the GPA medium showing the utilization of glucose as the carbon source. It is a confirmatory test for Rhizobium which utilizes glucose as carbon source (Kucuk et al., 2006).It was observed that rhizobial cells do not produce gelatinase enzyme, as the medium containing gelatin solidified when kept at $4^{\circ} \mathrm{C}$ for 30 as well as 60 minutes. Negative gelatinase activity is also a feature of Rhizobium (Hunter et al., 2007).Positive results were obtained from the starch hydrolysis assay. This indicates that the isolates have the potential to hydrolyze starch. Similar results were observed by Chitra Bhattacharya et al., 2013.

Rhizobium cells grown on King's medium under the UV source showed the absence of ability of the organism to fluoresce. Rhizobial cells utilized Mannitol as a source 
of carbon and changed the medium to yellow in color. On Bromothymol blue medium, fast growing rhizobia showed an acid reaction, turning the medium yellow (Fig.No.1)

The effect of Carbaryl and sodium chloride stress on Rhizobium was evaluated in this study. The insecticide and sodium chloride were incorporated in YEM medium at different concentrations and the growth pattern of Rhizobium in the medium was analyzed on the basis of change in growth. Total cell nitrogen was estimated by Micro Kjeldahl's method. Nitrogen fixation in legumes depends on the formation of nodules by Rhizobium. Without sufficient nodule mass filled with an efficient, nitrogen fixing strain of Rhizobium, nitrogen fixing will be inadequate. Inoculation of legume seed assures Rhizobium is present in the root environment. Rhizobium is a common soil bacterium and it is one of the most beneficial bacteria to agriculture.

Environmental stresses like temperature extremes, salinity, drought and nutrient supply have detrimental effects on nitrogen fixation (Biosca et al., 1996; Manhan and Steck, 1997; Denison and Kiers, 2004). In biological nitrogen fixation not only the micro but also the macrosymbiont plays an important role and their co-selection under given set of environmental conditions may enhance the amount of fixed nitrogen.

Detrimental effects of salt on growth and survival of Rhizobium have been reported (Saxena and Rewari 1992; Zahran, 1992). This may be due to the sensitivity of the host (Newcomb et al., 1979; Sprent 1984; Hafeez et al., 1988), the microsymbiont (Tu, 1981) or their symbiosis (Subba Rao et al., 1972). Tolerance towards high salt concentrations has been reported in several Rhizobium strains isolated from different saline soils that have shown to be efficient inoculants (Rasool et al., 1987; Elsheikh and Wood, 1995; Zou et al., 1995).

In this background, the rhizobial cultures isolated from legume, Arachis hypogaea, from different sites were analyzed for the tolerance to the different concentrations of sodium chloride. It was observed that all the 8 isolates and MTCC showed tolerance up to $0.800 \mathrm{M}$ sodium chloride (Fig No.2). Growth response analysis studies indicate that the strains had higher generation time in the presence of salt, rather than in the absence (Fig. No.3). Even though the strains were tolerant to salt concentrations, the fast growing organisms' adaptability to higher salt environment increased gradually which is reflected in the growth response analysis results. The gradual tolerance to sodium chloride suggests a chromosomal rather than a plasmid location of genes (MartinezRomero et al., 1991). Inoculation of stress tolerant strains of rhizobia may enhance the nodulation and nitrogen fixation ability of plants under stress conditions. The ability of legume hosts to grow and survive in saline conditions is improved when they are inoculated with salt tolerant strains of rhizobia (Zou et al., 1995; Hashem et al 1998; Shamseldin and Werner, 2005).

Pesticides are important tools of modern agricultural production that can protect crop yield and quality. A variety of pesticides are registered for use on legume crops. The majority of pesticides applied to crops eventually reach the soil, even if sprayed on the foliage of crop plants and weeds, which may affect the growth and activity of soil microbial communities (Cope 1971; Omar and Abdel-Sater 2001; Singh and Singh 2005). Extensive and excessive use of pesticide has aroused concern on their fate in soil and possible effects on soil microbial communities. 
In the current study, the rhizobial cultures isolated from legume Arachis hypogaea, from different areas were analyzed for resistance to the different concentrations of the insecticide Carbaryl. It was observed that all the isolates and MTCC showed resistance up to $2000 \mu \mathrm{g}$ of insecticide. The resistance hence is due to the capacity of the organism to overcome the stress of insecticide addition, utilize/detoxicate it to grow and multiply. The resistance to high levels of the insecticide could be due to the adaptations (Fig No. 4).Strain S5 had lesser generation time even in the presence of Carbaryl insecticide (Fig. No. 5). The isolated rhizobial strains resistance to the insecticide varied. Similar results were also observed by Gupta et al., 1981.

Total nitrogen assay by Micro - Kjeldahl's method (Ma Ts and Zuazaga G, 1942) evaluated the levels of nitrogen fixed easily. It was found that S1, S2, S5 and S6 isolates, showed a marked increase in nitrogen fixation by the organism cultured in the presence of insecticide. S3 showed a decrease in the nitrogen fixation and the other isolates showed an equivalent nitrogen fixation when compared with the isolates in the absence of insecticide. It is known that salt stress significantly reduces nitrogen fixation in legumes (Singleton et al., 1982). In this study, the amount of nitrogen fixed in the absence and in the presence of $0.800 \mathrm{M}$ sodium chloride was compared and it was observed that there was significant decrease in the amount of nitrogen fixed in the presence of $0.800 \mathrm{M}$ sodium chloride in all the isolates except S4 which had an equivalent nitrogen fixation even in the presence of $0.800 \mathrm{M}$ sodium chloride(Fig. No. 6).

The soil bacteria Rhizobium species in association with leguminous plants play vital role in agriculture. These bacteria have the capacity to convert free nitrogen into ammonium compounds in which can be readily absorbed by the plant system. This type of nitrogen helps in sustaining the growth of legumes by supplementing the nitrogen requirements.

The plant growth regulator indole acetic acid has long been postulated to play a role in one or more aspects of nodule growth and development and the detection of increased levels of IAA in nodules tissue supports this hypothesis. The associative nitrogen-fixing bacteria tested produced IAA, especially with tryptophan as a precursor.

In the current study, 8 isolates which showed resistance to $0.8 \mathrm{M}$ concentration of

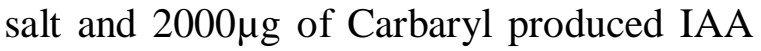
which was detected by the development of pink colour in the YEM medium supplemented with $1 \mu \mathrm{g} / \mathrm{ml}, 2 \mu \mathrm{g} / \mathrm{ml}$, and 5 $\mu \mathrm{g} / \mathrm{ml}$ of tryptophan. All isolated strains along with MTCC strain produced IAA in presence of tryptophan in present study (Fig. No.7). It was observed that as the concentration of tryptophan in the medium increases, the amount of IAA produced increased. No indole acetic acid production was observed in absence of tryptophan (control).Strain No.S5 was found to produce maximum amount of IAA when compared with the other strains. As established earlier, IAA production was dependent on the availability of tryptophan. In bacterial systems, the major pathway for IAA synthesis is a tryptophan dependent pathway. However, the isolates varied in their intrinsic ability to produce IAA as the production varied under the same condition.

When screened for EPS Production, all rhizobial isolates showed positive results and S5 was found to produce $35 \mu \mathrm{g} / \mathrm{ml}$ of EPS in the current study (Fig. No.7). Rhizobial EPS was shown to be involved in 
the Rhizobium-legume symbiosis. Skorupska et al. also reported that EPS may be involved in invasion and nodule development, bacterial release from infection threads, bacteroid development, suppression of plant defense response and protection against plant antimicrobial compounds. The EPS is economically important because it can impart functional effects to foods and confer beneficial health effects.

While observing the results for $\mathrm{HCN}$ production, positive results were noted. All the isolated rhizobial strains showed red colour orange formation on the filter paper. PGPR produced $\mathrm{HCN}$ to control growth of different growth of different type of pathogen (Bagnasco et al., 1998). The HCN producing rhizobia or bradyrhizobia inhibited the plant growth of soil borne pathogens but also these symbiotic bradyrhizobia and rhizobia produced some toxin, which inhibited the growth of fungi.

This stress tolerant plant growth promoting study on rhizobia of Arachis hypogaea suggests that the isolated strains which showed resistance to $0.8 \mathrm{M}$ salt concentration and $2000 \mu \mathrm{g}$ of carbaryl insecticide which were able to produce Indole Acetic Acid (IAA),EPS and HCN are efficient isolates of agricultural importance. Further studies are needed to understand the genetic adaptation of the organisms to various stress factors and field studies to be conducted to exploit the potential of the isolates as PGPR for sustainable plant growth.

Fig.1 Microbiological Assay of Rhizobial Isolates

\begin{tabular}{|c|c|c|c|c|c|c|c|c|}
\hline $\begin{array}{l}\text { Culture No. } \\
\text { Medium }\end{array}$ & S1 & S2 & S3 & S4 & S5 & S6 & S7 & S8 \\
\hline Gram Staining & $\begin{array}{l}\text { Gram } \\
\text { negative } \\
\text { rods }\end{array}$ & $\begin{array}{l}\text { Gram } \\
\text { negative } \\
\text { rods }\end{array}$ & $\begin{array}{l}\text { Gram } \\
\text { negative } \\
\text { rods }\end{array}$ & $\begin{array}{l}\text { Gram } \\
\text { negative } \\
\text { rods }\end{array}$ & $\begin{array}{l}\text { Gram } \\
\text { negative } \\
\text { rods }\end{array}$ & $\begin{array}{l}\text { Gram } \\
\text { negative } \\
\text { rods }\end{array}$ & $\begin{array}{l}\text { Gram } \\
\text { negative } \\
\text { rods }\end{array}$ & $\begin{array}{l}\text { Gram } \\
\text { negative } \\
\text { rods }\end{array}$ \\
\hline YEMA & $\begin{array}{l}\text { Mucoid } \\
\text { colonies }\end{array}$ & $\begin{array}{l}\text { Mucoid } \\
\text { colonies }\end{array}$ & $\begin{array}{l}\text { Mucoid } \\
\text { colonies }\end{array}$ & $\begin{array}{l}\text { Mucoid } \\
\text { colonies }\end{array}$ & $\begin{array}{l}\text { Mucoid } \\
\text { colonies }\end{array}$ & $\begin{array}{l}\text { Mucoid } \\
\text { colonies }\end{array}$ & $\begin{array}{l}\text { Mucoid } \\
\text { colonies }\end{array}$ & $\begin{array}{l}\text { Mucoid } \\
\text { colonies }\end{array}$ \\
\hline $\begin{array}{c}\text { GPA } \\
\text { (Glucose } \\
\text { utilization) }\end{array}$ & + & + & + & + & + & + & + & + \\
\hline $\begin{array}{c}\text { Gelatin } \\
\text { hydrolysis }\end{array}$ & - & - & - & - & - & - & - & - \\
\hline Starch hydrolysis & + & + & + & + & + & + & + & + \\
\hline $\begin{array}{c}\text { King's } \\
\text { medium(Fluoresc } \\
\text { ence assay) }\end{array}$ & - & - & - & - & - & - & - & - \\
\hline $\begin{array}{l}\text { Bromothymol } \\
\text { blue test }\end{array}$ & + & + & + & + & + & + & + & + \\
\hline Motility & $\begin{array}{l}\text { Highly } \\
\text { motile }\end{array}$ & $\begin{array}{l}\text { Highly } \\
\text { motile }\end{array}$ & $\begin{array}{l}\text { Highly } \\
\text { motile }\end{array}$ & $\begin{array}{l}\text { Highly } \\
\text { motile }\end{array}$ & $\begin{array}{l}\text { Highly } \\
\text { motile }\end{array}$ & $\begin{array}{l}\text { Highly } \\
\text { motile }\end{array}$ & $\begin{array}{l}\text { Highly } \\
\text { motile }\end{array}$ & $\begin{array}{l}\text { Highly } \\
\text { motile }\end{array}$ \\
\hline
\end{tabular}


Fig.2 Impact of Salt on the Growth of Rhizobial Isolates

\begin{tabular}{|c|c|c|c|c|c|c|c|c|c|}
\hline $\begin{array}{l}\text { Concentration } \\
\text { Strains }\end{array}$ & $\begin{array}{c}0.000 \\
M\end{array}$ & $\begin{array}{c}0.100 \\
M\end{array}$ & $\begin{array}{c}0.200 \\
M\end{array}$ & $\begin{array}{c}0.300 \\
M\end{array}$ & $\begin{array}{c}0.400 \\
M\end{array}$ & $\begin{array}{c}0.500 \\
M\end{array}$ & $\begin{array}{c}0.600 \\
M\end{array}$ & $\begin{array}{c}0.700 \\
M\end{array}$ & $\begin{array}{c}0.800 \\
M\end{array}$ \\
\hline S1 & + & + & + & + & + & + & + & + & + \\
\hline S2 & + & + & + & + & + & + & + & + & + \\
\hline S3 & + & + & + & + & + & + & + & + & + \\
\hline S4 & + & + & + & + & + & + & + & + & + \\
\hline S5 & + & + & + & + & + & + & + & + & + \\
\hline S6 & + & + & + & + & + & + & + & + & + \\
\hline S7 & + & + & + & + & + & + & + & + & + \\
\hline S8 & + & + & + & + & + & + & + & + & + \\
\hline MTCC & + & + & + & + & + & + & + & + & + \\
\hline
\end{tabular}

Fig.3 Growth Response Analysis to Sodium Chloride

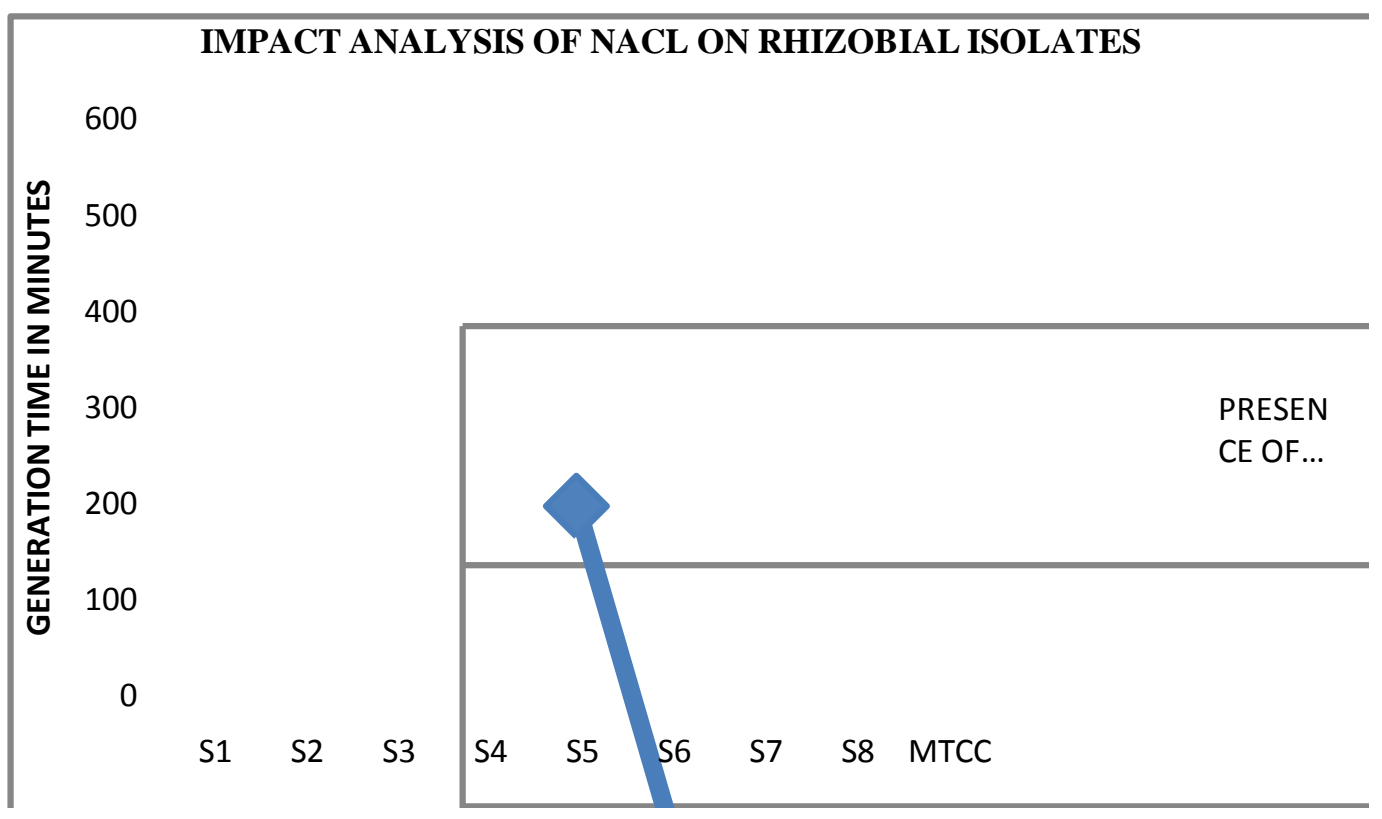


Fig.4 Impact Analysis of Insecticide on the Rhizobial Cultures

\begin{tabular}{|c|c|c|c|c|c|c|c|c|c|c|}
\hline \multirow[t]{2}{*}{ ISOLATES } & \multicolumn{10}{|c|}{ CONCENTRATION OF INSECTICIDE IN $\mu \mathrm{g} / \mathrm{ml}$} \\
\hline & 100 & 200 & 400 & 800 & 1000 & 1200 & 1400 & 1600 & 1800 & 2000 \\
\hline S1 & + & + & + & + & + & + & + & + & + & + \\
\hline S2 & + & + & + & + & + & + & + & + & + & + \\
\hline S3 & + & + & + & + & + & + & + & + & + & + \\
\hline S4 & + & + & + & + & + & + & + & + & + & + \\
\hline S5 & + & + & + & + & + & + & + & + & + & + \\
\hline S6 & + & + & + & + & + & + & + & + & + & + \\
\hline S7 & + & + & + & + & + & + & + & + & + & + \\
\hline S8 & + & + & + & + & + & + & + & + & + & + \\
\hline МТCC & + & + & + & + & + & + & + & + & + & + \\
\hline
\end{tabular}

Fig.5 Growth Response Analysis to the Insecticide Carbaryl

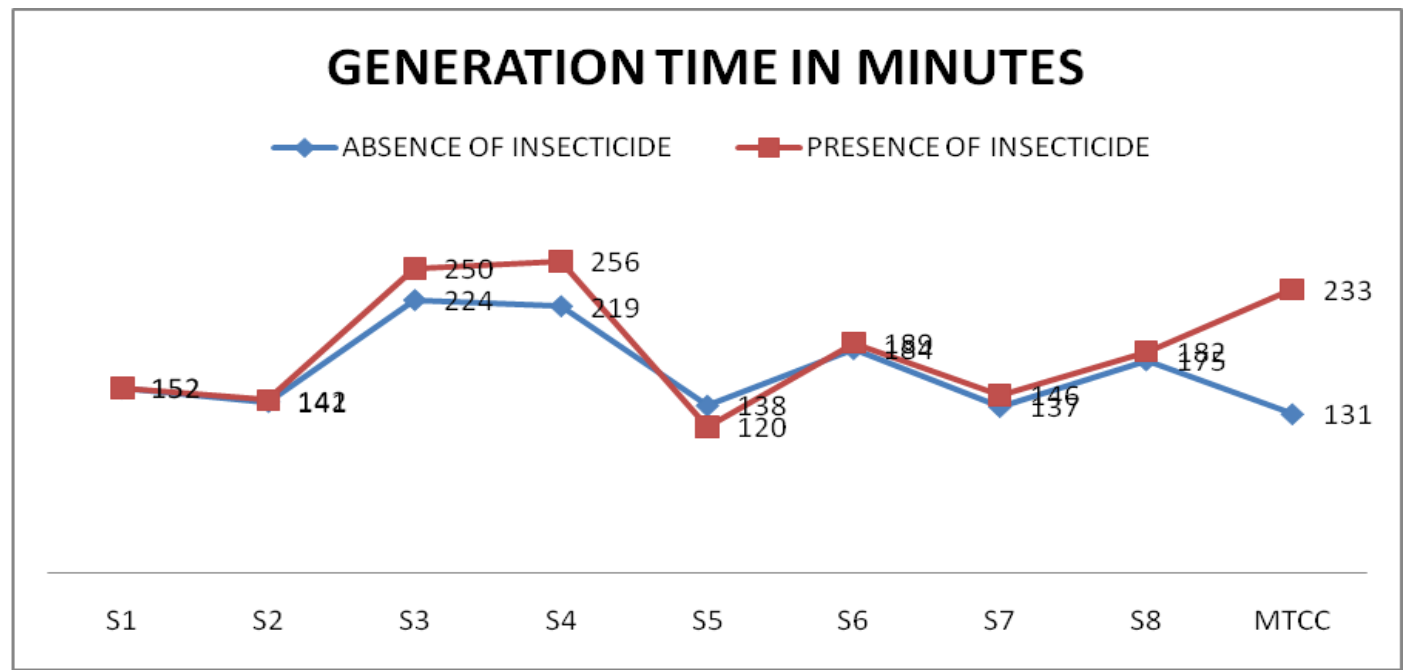


Fig.6 Estimation of Total Nitrogen Fixed by Micro Kjeldahl Method

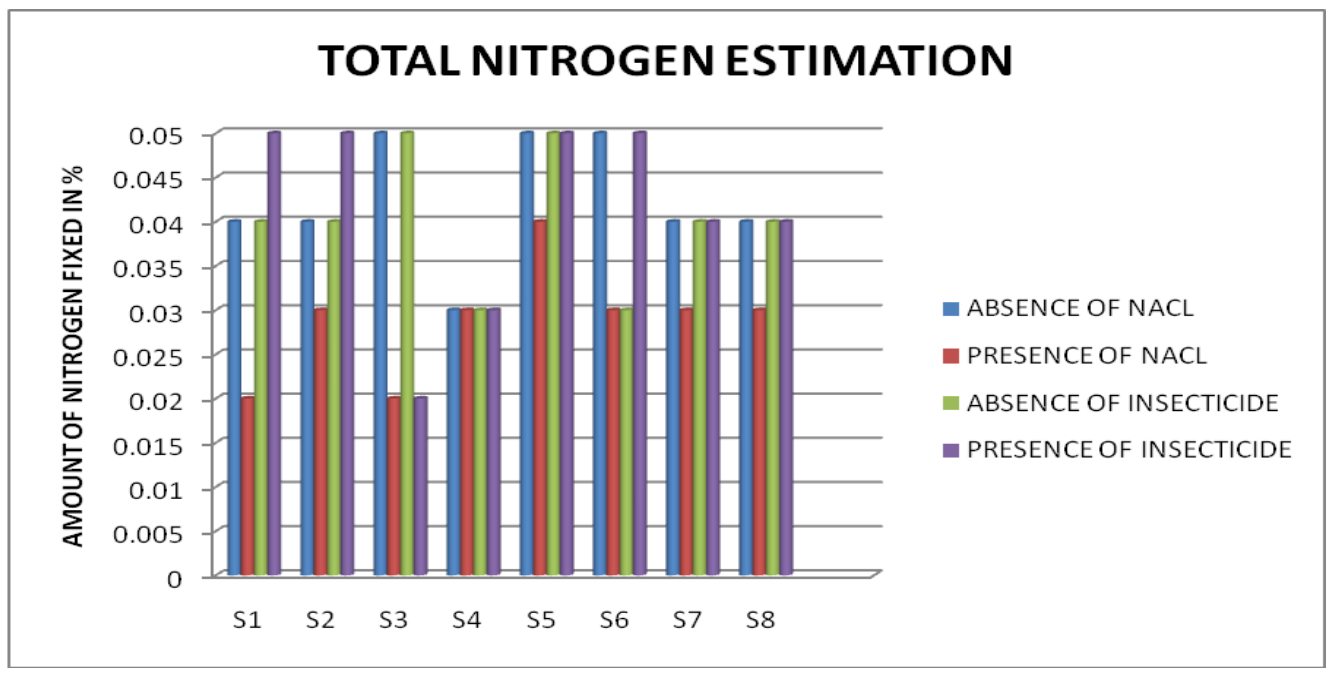

Fig.7 Results of Indole Acetic Acid and EPS Production

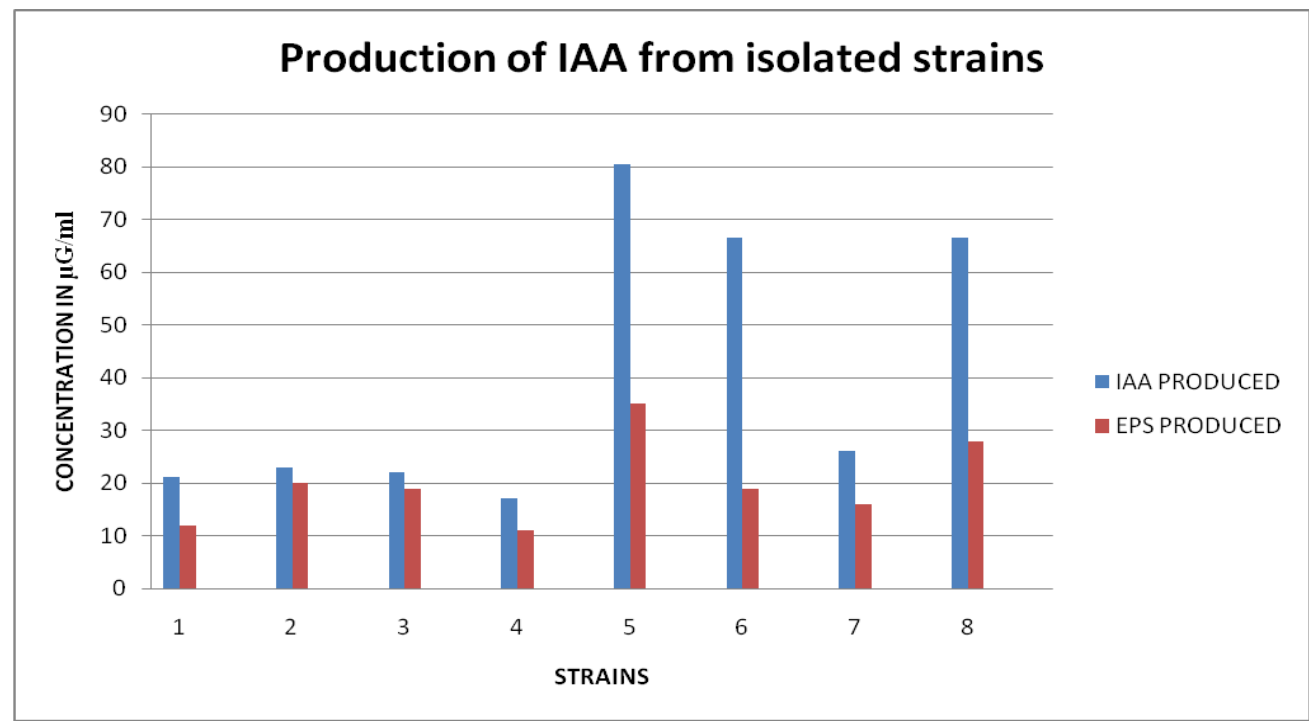

\section{References}

Abdel Wahab, A.M., H.H Zahran, and M.H. Abd-Alla. 1996. A Root - Hair infection and nodulation of four grain legumes as affected by the form and the application time of nitrogen fertilizer. Folia Microbial. 41 (4), 303 -308 .

Abdel Wanab. A.M., H.H. Zahran. 1981.
Effects of salt stress on nitrogenase activity and growth of four legumes. Biological Plantarum (praha) 23 (1), $16-23$.

Abdelmoumem.H, A. Fiali Matouf, M.Neyra, A. Belabed, and M. Missbah E1 Idrissi. 1999. Effect of high salts concentrations on the growth of rhizobia and responses to added osmotic pressure. Journal of Applied 
Microbiology. 86, 889 - 898.

Adlan, M.A.M. (1995). Response of Chickpea Nodulation, Nitrogen Fixation and Growth to Salinity. M.Sc. Thesis, Faculty of Science, American University of Beirut, Lebanon.

Aggarwal , T.C. Neeru Narula, and K. G. Gupta. 1986. Effects of some carbamate pesticide on nodulation, plant yield and nitrogen fixation by Pisum sativum and Vigna sinensis in the presence of their respective rhizobia. Plant and soil. 94. 125-132.

Alexander M (1984). Ecology of Rhizobium. In: Alexander M(ed) Biological nitrogen fixation: ecology, technology and physiology. Plenum, New York.. 39 - 50.

Alicja Niewiadomska and Justyna Klama. 2005. Pesticide side effects on the symbiotic efficiency and nitrogenase activity of Rhizobiaceae family. Polish Journal of Microbiology. 54 (1), 43-48.

Baljinder Singh, Ravneet Kaur and Kashmir Singh. (2008). Characterization of Rhizobium strain isolated from the roots of Trigonella foenumgraecum (fenugreek). African Journal of Biotechnology Vol. 7 (20).

Cenap Cevheri, Cigdem Kucuk and East Cetian. 2011. Fungicide, antibiotic, heavy metal resistance and sat tolerance of root nodule isolates from Vicia palaestina. Afr.J. Biotechnology 10 (13), 2423 - 2429.

Chaudri AM,McGrath SP,Giller KE(1992a). Metal Tolerance of isolates of Rhizobium leguminosarum biovar trifolii from soil contaminated by past applications of sewage sludge. Soil Biol. Biochem.24:83-88.

Munees Ahemad and Mohammad Saghir Khan Ecological assessment of biotoxicity of pesticides towards plant growth promoting activities of pea
(Pisum sativum)-specific Rhizobium $s p$. strain MRP1.

Elsiddig Ahmed Elmustafa Elsheikh. 1998. Respone of Legume-Rhizobium Symbiosis to Salinity in the Sudan. 6 (2).

Elsheikh, E.A.E. (1992). Effects of salinity on growth, nodulation and nitrogen yield of inoculated and nitrogen fertilized chickpea (Cicer arietinum L.). Archives of Biotechnology 1, 1728.

Elsheikh, E.A.E. and Wood, M. (1995). Nodulation and nitrogen fixation by Soybean inoculated with salt-tolerant rhizobia or salt-sensitive bradyrhizobia in saline soil. Soil Biology and Biochemistry 27,657-661.

Forawi, H.A.S. (1994). Effects of Salinity on Nodulation and Nitrogen Fixation of Fenugreek (Trigonella foenumgraecum). M.Sc. (Agric.) Thesis, Faculty of Agriculture, University of Khartoum, Sudan.

Hasshem FM, Swelim DM, Kuykendall LD, Mohamed AI, Abdel-Wahab SM, Hegazi NI (1998). Identification and characterization of salt and thermotolerant Leucaena nodulating Rhizobium strains. Biol. Fert. Soil. 27: 335-341.

Herridge DF, Peoples MB, Boddey RM (2008). Global inputs of biological nitrogen fixation in agricultural system. Plant Soil. 311: 1-8.

Hungria M,de O'Cheuerie LM, Coca RG, Megias M(2001). Preliminary characterization of fast growing rhizobia isolated from soybean nodules in Brazil. Soil Biol. Biochem.33:1349-1361.

Ijaz Mehboob, Zahir Ahmed Zahir, Muhammad Arshad, Asif Tanveer And Farooq-E-Azam. Growth Promoting Activities Of Different Rhizobium Spp., In Wheat. Pak. J. 
Bot., 43(3): 1643-1650,2011.

Jennifer E. Fox, Jay Gulledge, Erika Engelhaupt, Matthew E. Burrow And Johon A. McLachlan. 2007. Pesticides reduced symbiotic efficiency of nitrogen-fixing rhizobia and host plant. 104 (2).

Kucuk C, kivanc M, Kinaci E (2006).Characterization of Rhizobium Sp. Isolated from Bean. Turk. J. Biol. 30: 127-132.

Lin-Yuh Yueh and David L. Hensley 1993. Pesticide effects on acetylene reduction and nodulation of soybean and lima bean .J.Amer.Soc. Hort. Sci. 118 (1), 73-76.

Madhuri M. Sahasrabudhe. Screening of rhizobia for indole acetic acid production 2011, 2 (4) ; 460-468.

Martinez-Romero E, Segovia E, Mercante FM, Franco AA, Graham PH(1991). Rhizobium tropici, a novel species nodulating Phaseolus vulgaris L.beans and Leucaena sp.tress. Int. J Syst. Bacteriol. 41:417 - 426.

Mutluru Sridevi and Konada Veera Mallaiah. Bio production of indole acetic acid by Rhizobium strains isolated from root nodules of green manure crop, Sesbania sesban (L.) Merr. Iranian Journal of Biotechnology, Vol. 5, No. 3, 2007.

M.Sridevi and K. V. Mallaiah. Production of indole-3-acetic acid by Rhizobium isolates from Sesbania species African journal of Microbiology Research Vol. 1 (7) pp.125-128, 2007.

Odeyemi Olu and M. Alexander. 1977. Resistant of Rhizobium to Phygon, Spergon, Thiram. Applied and Environmental Microbiology. 33(4), 784-788.

Ramadoss S, Sivaprakasham K (1991).Effect of fungicides and insecticides on Rhizobium and Rhizobium - Cowpea Symbiosis. Soil
Fertil. 54(2):282.

Ranju Singla and Nera Garg. The Legume Symbiosis Under Salt Stress. Agric. Rev., 27 (1: 1-21, 2006.

R.C. Dubey, D. K. Maheshwari, Harish Kumar and Kamlesh Choure. Assessment of diversity and plant growth promoting attributes of rhizobia isolated from Cajanus cajan L. African journal of Biotechnology Vol. 9(50), pp. 8619-8629, 2010.

Sang Wan Gal and Young Ju Choi. Isolation and Characterization of Salt Tolerance Rhizobia from Acacia Root Nodules. Agric. Chm. Biotechnol. 46(2), 58-62 (2003).

S.P.Kale, N.B.K. Murthy, and K. Raghu. Effects of carbofuran, Carbaryl, and Their Metabolites on the Growth of Rhizobium sp. and Azotobacter chroococcum. Bull. Environ. Contam. Toxicol. (1989) 42:769-772.

Singleton PW, El Swaify SA,Bohlool $\mathrm{BB}(1982)$. Effect of salinity on Rhizobium growth and survival. Appl. Environ. Microbiol. 44: 884 - 890.

Steinborn , J. and R.J. Roughley. 1975. Toxicity of sodium and chloride ions to Rhizobium spp. In broth and peat culture.J. Appl . Bacterol., 39: 133138.

Sui-Sheng T.Hua, Victory. Tsai, Georgia M. Lichens and Amy T. Noma. 1982. Accumulation of amino acids in Rhizobium sp. strain RW1001 in response to Sodium chloride salinity. Applied and Environmental Microbiology. 44 (1), 135-140.

Tao, H. Brewin, N.J. and Noel, K.D. (1992) Rhizobium leguminosarum CFN42 lipopolysaccharide antigenic changes by environmental conditions. Journal of Bacteriology 174, 2222-2229.

$\mathrm{Tu} \mathrm{CM}(1981)$. Effect of fungicides on growth of Rhizobium japonicum and symbiotically grown soybean in 
soil under laboratory conditions. Prot.Ecol.3:41 - 46.

W.J.Hunter et al. (2007) Rhizobium species isolated from a Bioreactor. Curr. Microbiol. 55:455 - 460.

Yadav A K, Chandra K.(2014). Mass Production and quality control of microbial inoculants. Proc. Indian Natn Sci Acad.80: 483 - 489.

Yeo, A.R. and Flowers, T.J. (1989). Plants under stress, Biochemistry and Ecology and their Application to Plant Improvement, Cambridge Univ. Press, Cambridge, UK, pp. 217-234 successful Rhizobium legume symbiosis in saline environments. Bio. Fertil. Soil. 12, 73-80.

Zahran HH, Sprent JI (1986). Effects of Sodium Chloride and PEG on root hair infection and nodulation of Vicia faba L. plants by Rhizobium leguminosarum. Planta 167:303-309.

Zou N, Dart PJ, Marcar NE(1995). Interaction of salinity and rhizobial strain on growth and nitrogen fixation by Acacia ampliceps. Soil Biol. Biochem. 24: $409-419$.

Zaharan, H.H. 1991. Conditions for

\section{How to cite this article:}

Nithyakalyani, V., M.Kannan and Ramya Anandan. 2016. Insecticide and Salt Tolerance of Plant Growth Promoting Root Nodule Bacteria. Int.J.Curr.Microbiol.App.Sci. 5(4): 942-956. doi: http://dx.doi.org/10.20546/ijcmas.2016.504.107 